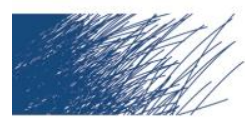

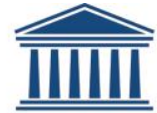 UNIVERSITEIT GENT
}

biblio.ugent.be

The UGent Institutional Repository is the electronic archiving and dissemination platform for all UGent research publications. Ghent University has implemented a mandate stipulating that all academic publications of UGent researchers should be deposited and archived in this repository. Except for items where current copyright restrictions apply, these papers are available in Open Access.

This item is the archived peer-reviewed author-version of:

Title Putting our heads together: Towards a syntax of particles.

Authors: $\quad$ Theresa Biberauer, Liliane Haqegeman, Ans van Kemenade

In:

Studia Linguistica: 2014:

Publisher:

pages

68:1: 1-15 


\section{Putting our heads together: towards a syntax of particles*}

Theresa Biberauer

Liliane Haegeman

Ans Van Kemenade

This special issue features five contributions focussing on the syntax of particles. The aim of this introductory essay is to contextualize the contributions in the linguistic literature and the issues that play a role in it.

The status of elements labelled 'particles' in the linguistics literature is somewhat ambivalent. On the one hand there seems to be overwhelming cross-paradigmatic consensus with respect to their identification: from functional to formal approaches the term particle is used to label elements such as those boldfaced in (1).

(1) a They finally gave in to political pressure.

b. Hij heeft het toch niet gedaan. (Dutch)

He has it PART not done

'He didn't do it after all.'

c. Heute hat er ja hier getanzt. (German, Struckmeyer, his (6c))

today has he PART here danced

'Today, he danced here.'

d. Tiens, j'ai trouvé la solution.

(French)

PART, I have found the solution

'Look, I have found the solution.'

At the same time, and as already shown by the examples in (1), the term 'particle' does not in any way represent a uniform or clearly defined category in the way that categories such as noun, verb, adjective, adverb are understood: their lexical meaning tends to be elusive and their functions include many types of grammatical marking (clause typing, case, tense, aspect, modality, evidentiality, negation, to name but a few), valency marking (causative, applicative

Liliane Haegeman's research is funded by FWO project 2009-Odysseus-Haegeman-G091409. 
etc.) discourse partitioning (topic, focus), and adpositional. The examples in (1) illustrate only a few of these: (1a) illustrates English verb particles, which, although many of them derive historically from adverbs, are now closely akin to (intransitive) prepositions, (1b) and (1c) illustrate modal particles as found in Dutch and German, which are in many respects similar to adverbs. The sentence initial particle tiens (lit. 'take') in French is morphologically derived from the imperative of the verb tenir ('take'). Data such as these underline that whatever unanimity there may appear to be on the status of particles is only superficial and results from the fact that the notion particle as such is a pre-theoretical concept lacking any analytical status.

Restricting ourselves at this point to formal approaches to syntax, the approach adopted by the authors in this volume, the label 'particle' covers what may appear to be a set of elements which are mostly identified negatively, in that, for instance, they lack inflectional endings, or they seem to occupy fixed positions (see especially Struckmeier, this volume, for this particular property). Because they are not inflected, particles also do not seem to be able to enter into agree relations within the clausal domain, and hence it is not clear to what extent they participate in the syntagmatic relations in a sentence. Semantically, most authors working on particles underline that their semantic contribution is difficult to capture, as the interpretation of particles seems to be to a large degree context dependent. Because particles very often encode properties relating to discourse effects and information structure, it is often impossible to fully characterise their function in terms of a sentence-oriented grammar (see, for example, Franck 1980 for a similar assessment). As a result, the first modern analyses of particles were mainly semantico-pragmatic and functional. Given that precise semantic descriptions has proved difficult to this day, some authors conclude that particles show that only a pragmatic take on their description can lead to any satisfying result (cf. Struckmeyer this volume).

This volume brings together five articles whose authors take a less defeatist attitude on the syntax of particles. All authors gathered here assume that particles have a place in the sentential syntax and all authors develop a precise account for a restricted set of particles. While authors do not adopt identical theoretical positions on the nature of particles, they converge in the assumption that particles can be analysed in terms of sentence-based syntax.

A further factor that adds to the terminological unclarity associated with the term 'particle' is that particles are far from uniform etymologically: they have been shown to derive from 
disparate sources, such as adverbs, pronouns, adjectives, verbs etc. Particles arise through processes of grammaticalization and pragmaticalization (where the latter is understood as grammaticalization of discourse functions, see e.g. Diewald 2011). This ties in in an interesting way with the observed categorial and semantic elusiveness of particles: processes such as grammaticalisation and pragmaticalization entail semantic bleaching, which may be characterized as a decrease in lexical meaning and an increase in grammatical meaning (Hopper and Traugott 2003; see e.g. van Kemenade (1999) for a brief formal characterization)

The approach to particles adopted by the contributors to this special edition is entirely compatible with an approach to grammaticalization cast in terms of a syntax-based perspective, as in e.g. van Kemenade (1999), Roberts and Roussou (1999; 2003), van Gelderen (2004). In such an approach, grammaticalization is analysed from a formal syntactic perspective according to which a lexical element which is initially associated with a functional phrasal head through syntactic movement, is reanalysed to functional head status, yielding a periphrastic expression. Following up the development of articulated clausal functional spines proposed in the wake of Rizzi (1997) and Cinque (1999), in which a wide variety of grammatical phenomena including a range of discourse marking functions are coded as functional heads in a crosslinguistically constant hierarchy, it is but a small step towards assuming that particles as the product of grammaticalization processes are instantiated as functional heads in the clausal spine.

While their theoretical positions are by no means identical, the contributors to this volume converge on the analytical assumptions as sketched above: In particular, the four contributions by Hack, Haegeman, Paul and Struckmeijer can be positioned against the backdrop of this general approach. Hack (this volume) studies the Dolomitic Latin particle po, showing that it has a number of functions: it may be a temporal adverb, corresponding to its original meaning 'then', but it may also encode modal readings, and in other contexts it has been grammaticalized from an adverb to a question marker, arguably located in a functional head. Haegeman considers a range of discourse related particles in West-Flemish which express speaker attitude, situating them in the functional domain at the clausal periphery. In independent work on the basis of Chinese clause-final particles Paul also postulates a functional layer that encodes speaker related properties. Her paper also addresses general issues concerning word order in Chinese. In his study of German modal particles, Struckmeijer analyses them as emergent functional heads in 
the VP periphery that spell out features related to speaker attitude. This precise syntactic framework allows him to provide detailed characterizations of the morpho-syntactic behaviour of particles.

The contribution by Elenbaas and van Kemenade is on the syntax of v-related particles in the history of English, and while their main goal is take issue with the influential position adopted by Kroch and associates that verb particles are diagnostics for basic word order (preverbal particles in an OV grammar, postverbal particles in a VO grammar), the analysis presented implies that in the course of the historical development of English particles were grammaticalized from full phrasal status to non-projecting words, as articulated in more detail in Los et. al. (2012: 93, where it is shown that the grammaticalization of verb particles reflects a very precise structural development according to the cline in (2):

a. $\quad$ stage $1\left[\mathrm{~V}, \ldots\right.$-XPRES $\left.\mathrm{V}_{0}\right]$ head of a full phrase

stage $2[\mathrm{~V}, \ldots[\mathrm{X}(\mathrm{P}) \mathrm{V} 0]$ optionally projecting word

stage $3\left[\mathrm{~V}^{\prime} \ldots\left[\mathrm{X} \mathrm{V} \mathrm{V}_{0}\right]\right.$ non-projecting word

stage $4\left[\mathrm{v}_{0} \ldots\left[\mathrm{X} \mathrm{V}_{0}\right]\right.$ quasi-incorporated word

stage $5\left[\mathrm{v} 0 \ldots\right.$... prefix $^{-\mathrm{V}]}$ prefix

b. phrase $\mathrm{XP}>$ particle $\mathrm{X}(\mathrm{P})>$ particle $\mathrm{X}>$ incorporated particle $\mathrm{X}>$ prefix

What unites the contributions in this volume then, is their attempt to provide precise mophosyntactic characterizations of a variety of particles which are themselves disparate in origin and nature, but whose common denominator appears to be that they are grammaticalized heads, with concomitant elusive meaning.

\section{Overview of the contributions}

Volker Struckmeier discusses the notorious modal particles (MP) in the German middle field illustrated by the boldfaced elements in (3):

(3) Dieser Satz enthält ja doch wohl viele Partikel. this sentence contains MP MP MP many particles

'This sentence contains many particles, doesn't it?' 
In contrast with much work in the literature (Cardinaletti 2011, Coniglio 2006, 2007), this author proposes that such Modal Particles constitute what he calls emergent functional heads rather than adverbs, and that they spell out clause type features in the middle field. The emergence of the particles is ascribed to a tendency in German to express grammatical properties periphrastically. It is argued that these particles can in fact be described as a homogeneous set of elements insofar as they interact with the $\mathrm{C}$ features of the containing clause. Once their clause type-related function has been acknowledged, it becomes clear that particles contribute substantially to the interpretation, precisely with regard to its clause type. It follows then that particles have to be accommodated in a clause-level grammar, and their interaction with $\mathrm{C}$ has to be explained by clause-internal, syntagmatic processes (see on the same point, Bayer and Obenauer (2011)).

The German MPs often occupy a position comparable to that of adverbs: Typically, modal particles occur in the Mittelfeld, i.e. they follow the finite verb (in C), but precede, for example, stranded quantifiers, which are arguably in SpecvP, cf. (4a)) or prototypically 'low' subjects, (such as indefinite wh-pronouns, cf. (4b)), which could be seen as being stranded in Spec $v$ P:

$$
\begin{aligned}
& \text { a. [СР Gestern haben [TP die Studenten eigentlich [vP alle gefeiert]]] } \\
& \text { yesterday have the students MP all celebrated } \\
& \text { 'The students all celebrated yesterday, actually' } \\
& \text { b. [CP Gestern hat [TP die Studenten ja [vP wer gesehen]]] } \\
& \text { yesterday has the students MP somebody seen } \\
& \text { 'Somebody saw the students yesterday.' }
\end{aligned}
$$

Struckmeier proposes that MPs merge in a specialized functional projection between TP and $v \mathrm{P}$. Semantic considerations determine the order in which MP heads merge into the projection line in the clause (see, for example, the proposal by Thurmair 1989: 288f.). Having no incentive to move, MPs stay in these base positions (MP-P) and thus never change their order.

$$
\text { [CP XP C [TP } \text { subject }_{\mathrm{i}} \ldots \text { [MP-P (MPs) [vP subject } \text { [vp }_{\mathrm{i}} \text { (objects) ... V]]]]] }
$$


One important feature of the German MP highlighted in this contribution is that their presence plays a role in determining clause type, implying that particles contribute to conveying what would ultimately be considered to be features of C (see also Bayer 2012 on the German particle denn). Thus, in a way, the particle projections invoked to account for the distribution and interpretation of German MP reduplicate what would standardly be taken to be CP related left peripheral features and projections. Observe that such a reduplication of C-properties in the middlefield is entirely in line with findings in other independent (cartographic) work on the functional structure. In parallel with the split CP as elaborated by Rizzi (1997) and much related work, there has been a tendency to propose that vP also disposes of a left periphery, as argued, for instance, in work by among others, Jayaseelan (1999, 2001, 2008, 2010), Butler (2003) and Belletti (2001, 2004, 2009). For these authors, the discourse related projections FocP and TopP postulated for the decomposed $\mathrm{CP}$ are replicated in discourse layers dominating vP.

Along the same lines, it has been argued that polarity emphasis may be expressed both by means of a particle in the specialised $\mathrm{CP}$ related projection and by a particle in a vP related projection. The reduplication of the encoding of polarity emphasis is illustrated for instance, in Catalan (Batllori \& Hernanz (to appear, fn. 14)), which has two particles to encode emphatic polarity. Both particles derive from the same adverb. The particle bé (6a), is a 'high' marker of polarity emphasis; the particle ben is a 'low' marker of polarity emphasis. The authors referred to take high be to be associated with the CP layer, while they assume that low ben shares properties with what Gallego (2007) calls mild focus: ben is taken to be merged at the left edge of $v \mathrm{P}$.
a. Bé
ha cantat la soprano
indeed
has sung the
soprano
'The soprano HAS sung'
b. La soprano s'ha
ben enfadat
the soprano $\mathrm{SE}=$ has BEN got-angry

'The soprano has really got angry'

(after Batllori \& Hernanz, to appear ) 
Kandybowicz (to appear) shows that the same duality arises in Nupe, where the clause-final particle ni: is argued to be a $\mathrm{CP}$ associated marker of emphatic polarity (7a), while verb doubling marks emphatic polarity on the edge of $\mathrm{vP}(7 \mathrm{~b})$ :

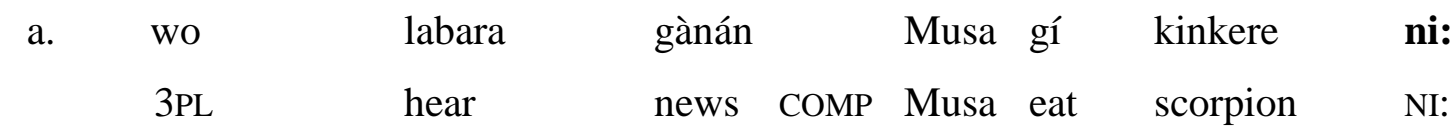

'(I assure you) They DID hear the news that Musa ate the scorpion.'

Not: '(I assure you) They heard the news that Musa DID eat the scorpion.'

(Kandybowicz to appear (4))

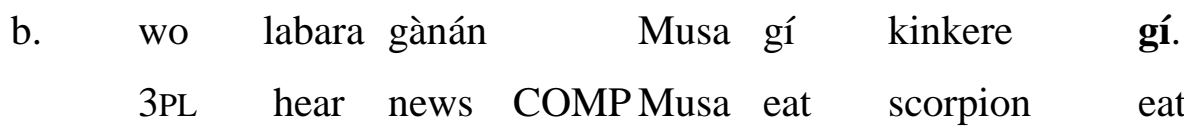

'They heard the news that (apparently) Musa DID eat the scorpion.'

(Kandybowicz, to appear (7))

Hack's contribution investigates the use of the particle $p o$ /pa in varieties of Dolomitic Latin, the particle originates as a temporal adverb analogous to English then and in contemporary dialects has a number of different uses.. First, po is used as a temporal adverb (8a) or as a marker of futurity (8b):

$$
\begin{array}{lll}
\text { a } & \text { Amor ... se fesh pa na berta. } & \text { (Badiot from 1925) } \\
\text { Amor ... himself make-3SG PA a trick } & \text { (Plangg 1989:659) } \\
\text { ' } & \text { Then Amor plays a trick on us.' } \\
\text { b. } & \text { Al vëgn } \quad \text { pa. } \\
& \text { he come-3SG PA } \\
\text { 'He will come. / He comes then.' }
\end{array}
$$

In addition, the particle may also express various modal and emphatic shades of interpretation, illustrated in (9): in (9a) the particle conveys impatience, in (9b-d) it conveys emphasis:

(9) a. Pó te digo!

(Anpezo) 
PO you say-1SG

(Croatto 1986:145)

'But I'm telling you, ...'
b. Al é pa bun!
(Badiot)
it be-3SG PA good
(Poletto \& Zanuttini 2003:183)
'It IS good!'
c. Fajé-1 pa dessigÿ!
(Badiot)
do-IMP=it PA definitely (2PL)
(Poletto \& Zanuttini 2003:183)
'Definitely do it!'
d. Ci bel ca l'e pa!
(Badiot)
how nice that it be-3SG PA
(Poletto 2000:66)
'How nice it is!'

As seen above, the particle may be associated with different clause types. Hack shows that the particle has acquired a more specialised use in interrogatives in which it realises various functions: it has a connecting function in (10a), it expresses modal meanings in (10b-c), and in some varieties it has developed a conventionalized use as a question particle as illustrated in (10d-e).
a. Olà vas=to pa?

where go-2SG=SCL PA

'Where are you going now (given that $\mathrm{x}$ has happened)?'
b. Ma će vọṣ=to pọ?
(Cortina d'Ampezzo)
but what want-2SG=SCL PO
(ALD-II)

'But what do you want then?'
c. Ulá pođạ́=si pa lćapẹ́?
(Ornela, Fodom)
where can-1SG=SCL PA it find
(ALD-II)

'Where (the devil) could I find it?'

$\begin{array}{llll}\text { d. Can compr=i } & *(p a) & \text { n liber? } \\ \text { when } & \text { buy-3pl=SCL } & \text { PA } & \text { a book }\end{array}$

(Gherdëina)

'When are they going to buy a book?' 

e. $\quad$ Ulà vas=te $*(p a)$ ?
(Badiot)
where go- $2 \mathrm{SG}=\mathrm{SCL} \quad \mathrm{PA}$
'Where are you going?'

It is shown that the particle po has undergone a grammaticalisation process, evolving from a temporal adverb via various stages such as that of a focus particle into an (obligatory) question marker.

Hack first describes the various functions of the particle (including those illustrated above) in some detail and she shows that the synchronic diatopic variation with respect to use and function of po mirrors the diachronic development of the particle. In the second part of the paper she addresses the syntax of the particle. The variation in Dolomitic Ladin interrogatives is taken in support of a split-CP analysis (Rizzi (1997, 2001), Poletto (2000, 2002), among others). The variation found in Dolomitic Ladin interrogatives is captured within Roberts \& Rousssou's $(1999,2003)$ formal approach to cross-linguistic variation showing that the Dolomitic Ladin facts corroborate an approach to grammaticalisation in terms of a change from the move to the merge option for the realisation of functional features.

Paul's contribution focuses on sentence Mandarin Chinese sentence-final particles which are argued to be related to the $\mathrm{CP}$ layer. She accounts for the rigid ordering of these Mandarin particles on the basis of an articulated CP à la Rizzi (1997) (cf. Paul 2005, 2009): three distinct layers are identified, which, moving from the lower to the higher projection, encode a decreasing connection to the content of TP and an increasing connection to the discourse participants.

(11) Attitude $>$ Force $>\mathrm{C}($ low $)>\mathrm{TP}^{1}$

The low C-particles such as le in (12) show a connection to the temporal reading of the clause. The interpretive impact of $l e$ is difficult to determine, and is subject to much discussion, but in one particular function, illustrated in (x), its role is to close off the sentence and relate the event

\footnotetext{
${ }^{1}$ Note that (11) abstracts from linear order.
} 
to the speech time indicating that it obtains as a new situation (whence Li \& Thompson's (1981) description of le as signaling "currently relevant state").

$$
\text { [СР [тP Wǒ zuótiān dào Zhāng jiā chī fàn ] le] }
$$$$
\text { 1SG yesterday go Zhang home eat food clow }
$$

'I went to the Zhangs for dinner yesterday.'

(Chao 1968: 798)

The 'intermediate' particles in (13) which are inserted in Force contribute to clause typing. The particle $m a$ indicating the yes/no question status of a sentence (cf. (13b)) was the first SFP to be analysed as C (cf. Lee Hun-tak 1986, Tang Ting-chi 1989). It is illustrated in (13):
a. Tā huì shuō zhōngwén.
3SG can speak Chinese
'He can speak Chinese.'
b. [CPforce [те Tā huì shuō zhōngwén] ma ]?
3SG can speak Chinese FORCE

Finally, Paul postulates a higher layer of C-related particles which encode the speaker/hearer's attitude, such as ou which is associated with a 'warning reminder' and $a$ which expresses 'astonishment' (cf. Chao Yuen Ren 1968: 803 ; 808). Consisting of a single vowel, these SFP are phonetically fused with a preceding SFP. (14) illustrates the particle ou:
(14) Bù zăo l'ou [=le +ou]! Kuài zǒu b'ou [=ba+ou]! NEG early PART (fusion) fast go PART (fusion)
'It's getting late! Hurry up and go!'

Apart from offering a classification and description of the Mandarin particles Paul also discusses the general syntactic status of the particles, raising questions as to their categorical nature and with respect to their relevance for universal constraints on word order (see also Elenbaas and Van Kemenade, this volume, for a different perspective on word order typology and particles). 
She starts from Biberauer et al. (2009)'s claim that clause-final particles are categorially deficient, a proposal motivated by the fact that a number of VO languages - among them Mandarin Chinese - display sentence-final particles (SFPs), which - if analysed as complementisers - would violate the purportedly universal Final-Over-Final Constraint (FOFC). The FOFC excludes structures where a head-final projection dominates a head-initial one. In contrast, Paul's article argues that SFP in Chinese instantiate C in a three-layered split CP and hence are "visible" for the FOFC.

The empirical focus of Haegeman's paper is a set of particles that appear on the clausal edge and are used as discourse markers (DM) in West Flemish (WF), a dialect of Dutch, and in the Flemish tussentaal. Apart from Haegeman (1984, 1993), which discusses the DM da, the empirical data presented here have not been discussed systematically in the generative literature.

The first part of the paper presents a brief overview of the distribution of WF sentenceinitial and sentence-final DMs. The second part of the paper analyzes the distribution of two specific DMs: $n \grave{e}(m)$ ('so there', 'take that'), and wè ('you know') and their relation to vocatives.

The particles that appear on the clause edge typically encode the speaker's attitude with respect to the (contents of) the speech act and/or with respect to the addressee. Many of these particles derive from verbs (see also Hill 2007a, 2007b, 2009 for similar particles in Romanian). All the DMs discussed are 'optional' in that an utterance remains grammatical if a DM is removed, but deletion of the DM results in a change in interpretation. Some examples are given in (15): wè, zulle and $d a$ are exclusively final, zé/zè and né/nè are initial or final, with subtle differences in interpretation:

(15) a. M' een al een medalie wè/zulle. we have already a medal we/zulle 'We already have a medal, you know.'

b. Een- ze al een medalie da? have they already a medal $d a$ 'Do they already have a medal?'

c. Zé/né, m’ een al een medalie. 
zélné, we have already a medal.

'Look, we already have a medal.

d. M' een al een medalie zè/nè.

we have alreadya medal, zè $/ n \grave{e}$

'We already have a medal, look.'

Like the authors discussed so far Haegeman assumes that particles should receive a syntactic analysis. On the basis of the distribution of the particles $n \grave{e}(m)$ and wè a hypothesis is elaborated concerning the syntactic representation of speech acts. In line with Hill's (2007a,b, 2009) work on Rumanian, postulates a speech act layer dominating ForceP and she assumes that particles head designated functional projections in the speech act layer.. Note that the speech act layer advocated here seems to coincide with Paul's higher C-layer, in that it encodes speaker attitude.

Haegeman further discusses the distribution of vocatives in relation with the particle. She assumes that PartP1 (headed by né in (16)) dominates PartP2 (headed by wè in (16)). The PartPs each select a specialized position for the vocative in SpecFP (as in (16)). (16a) represents the pattern with initial né and final wè; (16b) derives the combination of final wè and final né: PartP2, headed by wè, moves to the specifier of né.

$$
\begin{aligned}
& \text { a. }[\text { PartP1 }[\text { Part1 } n e ́][\mathrm{FP} 1 \text { voc }[\mathrm{F} 1] \quad[\text { PartP2 }[\mathrm{CP}][\text { Part wè }][\mathrm{FP} 2 \text { voc }[\mathrm{F} 2][\text { ForceP } \mathrm{CP}]]]]] \\
& \text { b. }[\text { PartP1[PartP2 }[\mathrm{CP}][\text { Part2 wè }][\mathrm{FP} 2 \text { Voc }[\mathrm{F} 2][\text { ForceP } \mathrm{CP}]]][\text { Part1 } n e ́][\mathrm{FP} 1 \text { voc }[\mathrm{F} 1][\text { PartP2 } \\
& \\
& \text { PartP2 }]]]
\end{aligned}
$$

Support of a different nature for the proposed syntactic treatment of discourse particles in terms of a speaker related functional domain is discussed in Miyagawa (2012), who examines the distribution of the so called 'allocutive inflection' of direct address in Souletin, a Basque dialect (cf. Oyharçabal (1993)). As shown by Miyagawa, this dialect can express the proposition 'Peter worked' in four distinct ways, depending on the gender/number of the addressee(s) and on the inter-personal relation between the speaker and the addressee. The relevant data are summarized in (17), from Miyagawa (2012: 81-2): in (17a), the sentence is uttered to a male friend, and (17b) 
to a female friend. The version in (17c) is appropriate for a hearer who is older or higher in status. (17d) shows that there is no plural allocutive. In order for the allocutive probe at $\mathrm{C}$ to be properly valued, it must find a goal within its local search domain. Much in the spirit of work by Speas and Tenny (2003), Hill (2007a,b, 2009) and by Haegeman and Hill (to appear), Miyagawa assumes that the relevant probe resides in a specialized speech act projection that dominates $\mathrm{CP}$.

\author{
a. To a male friend \\ Pettek lan egin dik. \\ Peter-ERG work-ABS do-PRF AuX-3.S.ABS-2.S.C.MSC.ALLOC-3.S.ERG \\ b. To a female friend \\ Pettek lan egin din. \\ Peter-ERG work-ABS do-PRF AuX-3.S.ABS-2.S.C.FM.ALLOC-3.S.ERG \\ c. To someone higher in status (formal) \\ Pettek lan egin dizï. \\ Peter-ERG work-ABS do-PRF AuX-3.S.ABS-2.S.F.ALLOC-3.S.ERG \\ d. Plural addressee \\ Pettek lan egin du. \\ Peter-ERG work-ABS do-PRF AUX-3.S.ABS-3.S.ERG
}

The contribution by Elenbaas and van Kemenade addresses the nature of particles like up, out, off, down, away in verb particle combinations in (the history of) English, and then goes on to address the role that such verb particles have played in the debate on basic word order (OV/VO) in early English

The authors provide extensive discussion of the status of particles at various historical stages of English, motivating an analysis of English verb particles as (optionally) projecting intransitive prepositions which function as (often resultative) secondary predicates, cast in terms of a lexical decomposition analysis of the verb particle combination. They outline the historical development of particles against the background of this analysis, showing that particles project to full phrasal level in Old English, and their meanings contribute to transparently compositional 
meanings for the verb particle combination. They go on to provide evidence that from the Middle English period onward, particles are grammaticalized to optionally projecting head status, and that this development goes hand in hand with the development of increasingly conventionalized and bleached meanings. This is illustrated by the examples in (18):

\section{a. Late Old English}

Đonne Moyses his handa up ahof, ...

(O3; cootest, Exod: 17.11.3063)

when Moses his hands up raised

'When Moses raised his hands, ...'

b. Early Middle English

Ha hackede of his heaued (M1; CMANCRIW, II.220.3190)

they cleaved off his head

'They cleaved off his head'

c. Early Modern English

... and tooke up a brick-bat which lay there by

(E2; ARMIN-E2-P2, 38.267)

'... and picked up a brickbat that lay near there'

d. Present-Day English

Recovering slightly from the terror of a moment ago, he wondered whether he dared pick up the skull.

(BNC, ACV 815)

(18a) is an example from Old English, in which the meaning of the particle is fully transparent and resultative; since particles can also be topicalized, they are taken to have full phrasal status as secondary predicates. In early Middle English as in (18b), particles are already predominantly in immediate postverbal position showing that they do not necessarily project to full phrasal level, and are perhaps incorporated with the verb. Their meaning is nevertheless usually transparent and resultative, as shown by (18b). Similar observation obtain for (18c) and (18d) from later stages of English.

Against the background of this analysis of verb particles, Elenbaas and van Kemenade address the contentious issue of the role that verb particles have played in the debate on OV/VO word order in early English, and in the Germanic languages generally. More precisely, the 
position of particles is often taken as a diagnostic for basic word order (OV/VO, where preverbal particles indicate an OV grammar, and postverbal particles a VO grammar.

Elenbaas and van Kemenade claim that, although there is a statistically strong crossGermanic correlation between the position of verb particles and verb complements, the position of verb particles is not a diagnostic for OV/VO order. To support this claim, they show that there is no one-to-one correspondence a) between Prt-V surface word order and an underlying OV grammar, or b) between V-Prt surface word order and an underlying VO grammar. They also show that OV order with DP-objects in early Middle English is highly discourse-sensitive, suggesting that OV order with DP-objects is not determined by phrase structure, but by discourse-sensitive scrambling from a VO base.

\section{References}

BAtLlori, M. and M.L. Hernanz. To appear. Emphatic polarity in Spanish and Catalan. Lingua, thematic issue: The syntax of polarity emphasis, eds. Anne Breitbarth, Karen Declercq, Liliane Haegeman.

BAYER, J. \& H.-G. OBEnAUER. 2011. Discourse particles, clause structure, and question types. The Linguistic Review 28, 449-491.

BAYER, J. (2012). From Modal Particle to Interrogative Marker: A Study of German denn. Functional Heads. The Cartography of Syntactic Structures, ed. L. Brugé, A. Cardinaletti, G. Giusti, N. Munaro \& C. Poletto, 13-28. Oxford: Oxford University Press.

Belletti, A., 2001. Inversion as focalisation. In: Hulk, A., Pollock, J.-Y. (Eds.), Subject Inversion in Romance and the Theory of Universal Grammar, Oxford University Press, Oxford, pp. 60-90.

Belletti, A., 2004. Aspects of the Low IP Area. In: Rizzi, L. (Ed.), The Structure of CP and IP. Oxford University Press, Oxford, pp. 16-51.

BelletTI, Adriana. 2009. Structures and strategies. Routledge: New York.

Biberauer, T., G. Newton, \& M. Sheehan, 2009. Limiting synchronic and diachronic variation and change: The Final-over-Final Constraint. Language and Linguistics 10.4, $701-743$. 
ButLER, J., 2003. A minimalist treatment of modality. Lingua 113, 967-996.

CARDinAlETt, A. 2011. German and Italian modal particles and clause structure. The Linguistic Review 28, 493-531.

CHAO, Y. R. 1968. A grammar of spoken Chinese. Los Angeles: California University Press.

CINQue, G. 1991. Adverbs and functional heads. Oxford: Oxford University Press.

Coniglio, M. 2006. German Modal Particles in the Functional Structure of IP. University of Venice Working Papers in Linguistics 16, 57-95.

Coniglio, M. 2007. German Modal Particles in Root and Embedded Clauses. University of Venice Working Papers in Linguistics 17, 109-141.

Croftto, E. 1986. Vocabolario Ampezzano. Cortina d'Ampezzo: Cassa rurale ed artigiana di Cortina d'Ampezzo.

DIEWALD, G. 2011. Pragmaticalization (defined) as grammaticalization of discourse functions. In: Degand, L. \& A-M. Simon-Vandenbergen (eds.). Linguistics 49, 2. 365-390.

FRANCK, D. 1980. Grammatik und Konversation. Frankfurt: Scriptor.

GALLEGO, Á.J., 2007. Defectivitat morfològica i variació sintàctica. Caplletra 42. 219- 249.

GELDEREN, E. van. 2004. Grammaticalization as Economy. Amsterdam: John Benjamins.

HaEgeman, L. \& V. HiLl. To appear. The syntacticization of discourse. In Raffaella Folli, Christina Sevdali \& Robert Truswell (eds.), Syntax and its limits. New York \& Oxford: Oxford University Press.

HAEGEMAN, L. 1984. Interjections and phrase structure. Linguistics 22, 41-49.

HAEGEMAN, L. 1993. The interpretation of the particle da in West Flemish. Lingua 90, 111-128.

HILl, V. 2007a. Romanian adverbs and the pragmatic field. The Linguistic Review 24, 61-86.

HILL, V. 2007b. Vocatives and the pragmatics-syntax interface. Lingua 117, 2077-2105.

HILL, V. 2009. Messengers at the pragmatics-syntax interface: the pragmatic role markers in vocatives. Paper presented at the Interfaces 2 conference: University of Kent (Canterbury), May 5-7.

Hopper, P. \& E. Traugott. 2003. Grammaticalization. Cambridge and New York: Cambridge University Press.

Jayaseelan, K., 1999. A Focus Phrase above vP. Proceedings of the Nanzan GLOW, Nanzan University, Nagoya, 195-212. 
JayaseElan, K., 2001. IP-internal Topic and Focus Phrases. Studia Linguistica 55. 39-75.

JAYASEELAN, K., 2008. Topic, focus and adverb positions in clause structure. Nanzan Linguistics 4. $43-68$

JAYASEELAN, K., 2010. Stacking, stranding, and pied-piping: a proposal about word order. Syntax 13, 298-330.

KANDYBOWICZ, J., to appear. Varieties of polarity emphasis: restricted and unrestricted expressions in Nupe. Lingua, thematic issue: The syntax of polarity emphasis, eds. Anne Breitbarth, Karen Declercq, Liliane Haegeman.

KeMENADE, A. van. 1999. Functional categories, morphosyntactic change, grammaticalization. Linguistics 37.6, 997-1010.

LEE, Hun-tak T. 1986. Studies on quantification in Chinese. University of California at Los Angeles: Ph.D. dissertation.

Li, C. N. \& Thompson, S. A. 1981. Mandarin Chinese. A functional reference grammar. Los Angeles: California University Press.

Los, B., C. Blom, G. Boois, M. ElenbaAs \& A. VAn Kemenade. Morphosyntactic Change: a Comparative Study of Particles and Prefixes. Cambridge and New York: Cambridge University Press.

MiYagAwA, Shigeru. 2012. Agreements that occur mainly in the main clause. In Aelbrecht, Haegeman and Nye (eds). Main Clause Phenomena. New Horizons, John Benjamins, Amsterdam. 79-112.

OYHARCABAL, Benat. 1993. Verb agreement with non arguments: On allocutive agreement. In Generative Studies in Basque Linguistics [Linguistik Aktuell/Linguistics Today 105], Jose Ignacio Hualde \& Jon Ortiz de Urbina (eds), 89-114. Amsterdam: John Benjamins.

PAUL, W. 2005. Low IP area and left periphery in Mandarin Chinese. Recherches linguistiques de Vincennes 33, 111-134.

PAUL, W. 2009. Consistent disharmony: sentence-final particles in Chinese. Ms., CRLAO, Paris. Available at: http://ling.auf.net/lingBuzz/001021. PlangG, G. 1989. Ladinisch: Sprachgeschichte I. Grammatik. Lexikon der Romanistischen Linguistik. Vol III, ed. G. Holtus, M. Metzeltin \& C. Schmitt, 646-667. Tübingen: Niemeyer.PoletTO, C. 2000. 
The Higher Functional Field. Evidence from Northern Italian Dialects. Oxford: Oxford University Press.

POLETTO, C. 2002. The left-periphery of V2-Raetoromance dialects: a new view on V2 and V3. Syntactic Microvariation. Proceedings of the workshop on syntactic microvariation. Amsterdam August 2000, ed. S. BARBIERS; L. CORNIPS \& S. VAN DER KLEIJ, 214-242. Amsterdam: Meertens Institute.

[http://www.meertens.knaw.nl/books/synmic/pdf/poletto.pdf; last accessed 27 August 2012]

Poletto, C. \& R. ZAnuttini. 2003. Making Imperatives: evidence from Central RhaetoRomance. The Syntax of Italian Dialects, ed. C. Tortora, 175-206. Oxford: Oxford University Press.

RIZZI, L. 2001. On the position "Int(errogative)" in the left periphery of the clause. Current Studies in Italian Syntax. Essays offered to Lorenzo Renzi, ed. G. Cinque \& G. Salvi, 287295. Amsterdam: Elsevier.

Rizzi, L., 1997. The Fine Structure of the Left Peripery. In: Haegeman, L. (Ed.), Elements of Grammar: Handbook in Generative Syntax, Kluwer, Dordrecht, pp. 281-337.

RoBERTS, I. \& Roussou, A. 1999. A formal approach to “grammaticalization”. Linguistics 37(6), 1011-1041.

Roberts, I. \& Roussou, A. 2003. Syntactic change. A minimalist approach to grammaticalization. Cambridge: Cambridge University Press.

SPEAS, Peggy \& TENnY, Carole. 2003. Configurational properties of point of view roles. In Asymmetry in Grammar [Linguistik Aktuell/Linguistics Today 57-58], Anna-Maria Di Sciullo (ed.), 315-344. Amsterdam: John Benjamins.

TANG, T. 1989. Hanyu cifa jufa lunji [Studies on Chinese Morphology and Syntax], vol. 2. Taipei: Student Book Co.

ThurmaIR, M. 1989. Modalpartikeln und ihre Kombinationen. Tübingen: Max Niemeyer. 